\title{
Нові форми інформаційної взаємодії масмедіа УГКЦ у суспільному контексті під час пандемії коронавірусу
}

\author{
Ігор СКЛЕНАР \\ канд. н. із соц. комунік., доц. \\ Львівський національний \\ університет імені І. Франка \\ вул. Симоненка 12/4, \\ Львів, Україна, 79071 \\ isklenar@gmail.com \\ ORCID ID 0000-0003-2081-2199 \\ (C) Скленар I., 2021
}

Пандемія коронавірусу з березня 2020 року спонукала УГКЦ, як і інші конфесії, використовувати засоби онлайну через те, що Урядом України під час жорстко20 карантину було встановлено обмеження для перебування у культових спорудах. Основною метою статті є розгляд низки форм інформаційної взаємодії УГКЦ у суспільному контексті.

Із допомогою методу аналізу констатовано, що станом на початок 2021 року в греко-католицьких ЗМІ в Україні є мала частка друкованих періодичних видань, які, на переконання експертів, потребують якісного наповнення. Натомість офіційні ресурси Церкви почали за останні роки свій розвиток у різних форматах. Застосування методу контент-аналізу, а також методу моніторингу допомогло стисло висвітлити те, як якісні ЗМІ в Україні представляють УГКЦ у добу пандемії, у тому числі з допомогою інтерв'ю зі знаковими постатями в релігійній сфері.

Результатом дослідження у статті стало визначення форм інформаційної взаємодії УГКЦ у суспільному контексті на двох рівнях - загальноукраїнському й місцевому. Зауважено, що на першому рівні провідну роль відіграли основні офіційні медіаресурси УГКЦ, зокрема, проєкт «Живе телебачення», підтриманий також національними каналами. Вони транслювали літургії в жорстку фазу пандемії. На місцевому рівні парафії (малі церковні одиниці в Церкві) стали осередками залучення вірян у мережу з допомогою різних онлайн-інструментів. Сторінки в соціальних мережах священнослужителів із різних парафій, проєкти на Үоитиве парафіяльних священників, монахів із різних спільнот тощо - це нові форми інформаційної взаємодії Церкви в добу пандемії, які також розглянуто в пропонованому дослідженні.

Стисло представлено досвід медійної діяльності Католицької Церкви в Італії та Польщі в жорстку фазу коронавірусу, напрацювання такої діяльності в статті порівняно з формами інформаційної взаємодії УГКЦ.

Перед дослідниками із різних сфер - журналістикознавцями, релігієзнавцями, богословами, соціологами та ін. - після можливого закінчення пандемії коронавірусу виникне низка цікавих тем для вивчення феномену медійної діяльності УГКЦ та інших конфесій у взаємозв'язку із глобальними релігійними й культурними процесами у світі загалом.

Ключові слова: пандемія, інформаційна взаємодія, ЗМІ УГКЦ в Україні, соціальні мережі, канал Yоutube. 


\title{
NEW FORMS OF THE UGCC MASS-MEDIA INFORMATION INTERACTION IN THE PUBLIC CONTEXT DURING THE CORONAVIRUS PANDEMIC
}

\author{
Ihor Sklenar \\ $\mathrm{PhD}$ in Social Communications, Associate Professor \\ Ivan Franko National University of Lviv \\ 12/4, Symonenko St., Lviv, Ukraine, 79071 \\ isklenar@gmail.com \\ ORCID ID 0000-0003-2081-2199
}

The Coronavirus pandemic since March 2020 has prompted the UGCC, like other denominations, to use online means because the Government of Ukraine imposed restrictions on religious buildings during the strict quarantine. The main purpose of the article is to consider a number of the UGCC information interaction forms in the social context.

Using the method of analysis, it was stated that as of the beginning of 2021, in the Greek Catholic media in Ukraine, there is a small share of printed periodicals, which, according to experts, need quality content. Instead, in recent years the official resources of the Church have begun to develop in various formats. The application of the content analysis method and also the monitoring method helped to briefly highlight how high-quality media in Ukraine represent the UGCC in the days of the pandemic, including through interviews with iconic figures in the religious sphere.

The result of the research in the article was to determine the forms of the UGCC information interaction in the social context at two levels - all-Ukrainian and local. It was noted that at the first level, the leading role was played by the main official media resources of the UGCC, in particular, the Zhyve TV project, which is also supported by national channels. They broadcast liturgies in the hard phase of the pandemic. At the local level, parishes (small church units in the Church) have become centers for engaging believers in the network through various online tools. Pages on social networks of priests from different parishes, Youtube projects of parish priests, monks from different communities, etc. are new forms of information interaction of the Church in the pandemic era, which are also considered in this article.

The experience of the Catholic Church media activity in Italy and Poland in the hard phase of Coronavirus is also briefly presented, and the work of such activity in the article is compared with the forms of the UGCC information interaction.

After the possible end of the Coronavirus pandemic, many interesting topics will arise to study the phenomenon of media activity of the UGCC and other denominations in connection with global religious and cultural processes in the world as a whole before researchers from various fields - journalists, theologians, divines, sociologists and others.

Keywords: pandemic, information interaction, UGCC mass media in Ukraine, social networks, Youtube channel. 


\section{Актуальність проблеми}

Запровадження жорсткого карантину минулоріч поставило УГКЦ, як і інші релігійні організації, перед викликом і надалі доносити віровчення та літургійні практики до своїх вірян у зв’язку з тим, що Урядом України під час жорсткого карантину було встановлено норму, щоб у культовій споруді не перебувало більш ніж десять осіб під час звершень богослужінь та молитовних практик. Станом на початок 2021 року УГКЦ із допомогою нових медіа вже напрацювала нові форми інформаційної взаємодії із зацікавленою аудиторією для донесення Слова Божого, не тільки серед своїх вірних, а й серед загалу християн.

Стан вивчення проблеми

Ця тема $€$ новою в сегменті студій із релігійної журналістики в українському інформаційному просторі (одним із дослідників цієї нішевої журналістики є й автор пропонованої статті). Базовими для розгляду обраної теми стали наукові праці дослідників релігійної журналістики в Україні (Бойко, 2016; Гадьо, 2020; Блажиєвський, 2020 та ін.), які подають як огляди греко-католицьких медіа, так і розглядають роль і місце новітніх технологій в інформаційній політиці УГКЦ. Основні вебресурси УГКЦ в Україні та Youtube-канали і сторінки в соціальних мережах деяких священнослужителів Церкви стали емпіричною основою для матеріалу статті. Публічні виступи у світських та релігійних масмедіа ієрархів УГКЦ, зокрема, Блаженнішого Святослава (Шевчука), деяких священників, зокрема, монаха Студійського Уставу УГКЦ Юстина Бойка, у дечому висвітлили тему нових форм спілкування Церкви зі своєю аудиторією під час пандемії (Жадан, 2020; Телеканал НТА, 2020).

У Європейському Союзі вже має місце подібний досвід інформаційної взаємодії Католицької Церкви зі своїми вірянами в часі обмежень. На Міжнародній науковій конференції «Віртуалізація суспільного життя в умовах пандемії» в Технічно-Гуманітарній академії в Бєльсько-Бялій (Польща) 17 грудня 2020 року, в якій автор статті брав участь і зреферував доповіді для свого наукового архіву, дослідниками з різних освітніх інституцій було, зокрема, показано й нові форми спілкування Католицької Церкви в часі пандемії (Kindziuk, 2020; Radwańska, 2020). Не менш важливе в контексті цієї розвідки є одне із досліджень італійських науковців про присутність парафій у соціальних мережах, оприлюднене на сторінках італійської газети «Avvenire» (Lenzi, 2021).

Невирішеними питаннями в обраній темі є дійсне число форм інформаційної взаємодії УГКЦ із суспільством на загальноукраїнському й місцевому рівнях, реальна кількість учасників діалогу - священнослужителів УГКЦ - і також громадських лідерів цієї конфесії 
на різних медійних майданчиках і платформах у соціальних мережах тощо.

\section{Завдання статті}

По-перше, робимо стислий огляд ЗМІ УГКЦ в Україні станом на початок 2021 року; по-друге, показуємо на основі матеріалів 3MI фрагментарно образ Церкви в період пандемії у 2020 році; по-третє, визначаємо основні медійні ресурси УГКЦ як ефективні засоби інформаційної взаємодії, які були використані на загальному й місцевому рівнях релігійного життя цієї конфесії в період пандемії з березня 2020 року до січня 2021 року.

Виклад основного матеріалу

За статистикою, кількість ЗМІ УГКЦ в Україні, зареєстрованих державними органами влади, коливається в межах 30-ти назв (друковані, аудіовізуальні, вебресурси).

За аудиторними ознаками дослідники поділяють масмедіа УГКЦ на офіuійні (офіційний сайт УГКЦ - www.ugcc.org.ua, інформаційний сайт УГКЦ - news.ugcc.org.ua, інтернет-телебачення «Живе.ТВ»zhyve.tv і «Живе радіо» (до 2015 року радіо «Воскресіння»); медіаресурс УГКЦ - ugcc.tv; «Собор УГКЦ» - ресурс представляє матеріали зібрань духовенства УГКЦ (Собор на різних рівнях) sobor-ugcc.org.ua; для широкої аудиторії (суспільно-релігійний часопис «Патріярхат»www.patriyarkhat.org.ua; сайт «Католицький оглядач» - активний iз 2010 р. до 2020 р. за посиланням catholicnews.org.ua; часопис «Miсіонар» - сайт https://misionar.in.ua/; журнал «Скинія» (3 2013 року), сайт https://skynia.org/; журнал Київської Архиєпархії УГКЦ «Наш Собор», сайт https://ugcc.kiev.ua/zhurnal-nash-sobor/; газета Львівської Архиєпархії «Мета», сайт https://www.meta-ugcc-lviv.com/ та ціла низка єпархіальних газет (у світському значенні це «регіональна преса»). Виділяють ще ЗМІ для молодіжної аудиторії (наприклад, сайт Патріаршої молодіжної комісії «Дивенсвіт» https://dyvensvit.org/ та ін.); для сімейного читання (сайт спільноти молодих подружь «Сім'я» - www. simya.org.uа та ін.) (Бойко, 2016, с. 156-160).

Найновіша статистика, поки що станом на 1 січня 2020 року, яку подає Міністерство культури України, фіксує: «релігійними організаціями видається 325 періодичних видань». Їхня кількість, порівнюючи із 2019 роком зменшилася на 16 назв («В Україні зросла кількість», 2020). Те саме стосується й періодики УГКЦ - протягом кількох останніх років через економічні труднощі деякі спеціалізовані журнали УГКЦ зникли з інформаційного простору.

Дослідниця 3 Інституту журналістики КНУ імені Т. Шевченка А. А. Бойко наголошує, що з початку 90-х років УГКЦ в Україні на різних рівнях почала відновлювати свою періодику (заборонену комуністичною владою з 1944 року здебільшого на Заході України). Біль- 
шість часописів допомагають читачам керуватися християнськими принципами в житті, у спілкуванні з іншими людьми - друзями, родичами, близькими, дітьми, співробітниками тощо. Багато уваги приділено питанням суспільно-політичного життя: тлумаченню засад демократичного суспільства, ролі й відповідальності християнина в процесі формування державного устрою, прищепленню толерантності, вихованню милосердя тощо. На сторінках греко-католицької преси публікують матеріали з історії України та Церкви, зокрема, її катакомбного періоду в 1946-1989 pр. В останні роки висвітлюють і діяльність капеланів УГКЦ на Донбасі.

Дослідники релігійних ЗМІ не тільки вивчають кількісний стан ЗМІ УГКЦ в Україні, а і критично оцінюють їх у зв’язку із нестачею якісної релігійної інформації в нашому інформаційному просторі. Наприклад, докторант у ділянці соціальної комунікації Університету Святого Хреста (католицького навчального закладу в Римі), головний редактор греко-католицького журналу «Скинія» о. Юрій Блажиєвський наголошує в одному з інтерв’ю для інтернет-видання «Релігійно-інформаційна служба України»: «фактична відсутність релігійних медіа в країні, тобто, здебільшого їхній дуже низький кількісний і якісний рівень, створює таку ситуацію для загальноукраїнських чи регіональних медіа, у якій відсутнє експертне середовище. Тоді редакції 3МІ звертаються за коментарями до церковних ієрархів (які не можуть бути експертами в усьому), іноді до якогось релігієзнавця, який не завжди має відповідний рівень знань, і це породжує проблеми при висвітленні релігійної тематики» (Блажиєвський, 2020). Тому, на його переконання, ключем до вирішення проблеми $є$ підвищення якості релігійних медіа, які би ставали автентичними й перевіреними партнерами для світських медіа.

Перед розглядом інформаційної взаємодії УГКЦ розглянемо суспільний контекст, у якому деякі світські медіа (чи то загальноукраїнські, чи регіональні) представляли Церкви в Україні на початку пандемії й запровадження жорсткого карантину. Це був переважно образ «порушника норм карантинних обмежень» і це було пов'язано частково з позицією деяких владик РПЦ в Україні (хоч офіційна назва цієї конфесії ще досі УПЦ - прим. І.С), зокрема, і монахів із Києво-Печерської Лаври, цинічна поведінка яких щодо недотримання карантину й невіра в небезпеку від хвороби була показана в провідних 3МI. Доля зіграла з ними в злий жарт - частина духовенства заразилася і важко перенесла хворобу, дехто з монахів помер. До створення такого негативного образу Церкви переважно були причетні телеканали, які належать олігархам, і де транслювали сюжети з абсолютним невіглаством щодо релігійних питань (Телеканал НТА, 2020). Натомість позитивні приклади того, як УГКЦ лікує душі людей у час кризи, чи 
коментарі компетентних осіб із релігійного середовища про віру в період пандемії рейтингові телеканали майже ігнорували.

Водночас деякі якісні друковані 3МІ на своїх сторінках в інтернеті за суттю стали ретрансляторами позиції Церков в Україні, у тому числі УГКЦ, тобто почали активніше вводити релігію в публічний дискурс. У проєкті «Погляди» на сайті «Новое время»єпископ Борис Гудзяк, Президент УКУ, митрополит Філадельфійський УГКЦ у США регулярно публікує тематичні колонки на тему ролі релігії й Церкви. Так, в одній із колонок він описав власний досвід підготовки до свята Великодня в США в контексті духовних викликів, зумовлених епідемією. Хоча, на думку автора, боляче переживати закриття храмів, усе ж «зараз ми маємо можливість обирати стріми Літургій та проповідей на будь-який смак, обсяг релігійного контенту за час карантину зріс у кілька разів, а в час радянської влади за прослуховування Літургії на «Радіо Ватикан», якщо трансляцію не заглушили, можна було отримати серйозні неприємності на роботі, в університеті чи школі», нагадав єпископ-блогер болючий досвід тоталітарних часів в Україні (Гудзяк, 2020).

Слово Блаженнішого Святослава на тему коронавірусу також стало помітним на якісних медіаресурсах, переважно в жанрі інтерв’ю. Одне зі знакових - в авторській програмі письменника Сергія Жадана на «Радіо НВ» на початку листопада 2020 року заторкує й тему пандемії коронавірусу в контексті нових технологій: «... починаємо щораз глибше усвідомлювати, як нам можна використовувати ті сучасні засоби спілкування, наприклад, в умовах пандемії, коли фізично зібрати людей ми не можемо. Але теж до певної міри бачимо, що тут $є$ така сильна межа. Наприклад, ми можемо спілкуватися онлайн, але когось виховувати онлайн чи любити онлайн...», - резюмував глава УГКЦ (Жадан, 2020). Пандемія, за його словами, вдарила в саме серце церковного буття, тому що Церква - це є асамблея, збирання людей, «екклезія»- це є зустріч тих, хто є скликаний, хто є покликаний. В українській мові, як зауважує Блаженніший Святослав, слово «спільнота» $є$ дуже клерикальним словом, «тут ми знову говоримо про діалог із культурою» (Жадан, 2020). Пандемія коронавірусу, за словами ієрарха, стала пограничним досвідом. Люди вже ніколи не будуть такими, як до настання цієї пандемії. На його думку, ми, люди, можемо з тієї пандемії вийти кращими. «Чому?... Я думаю, що цей момент (період пандемії - прим. І.С.) є доброю нагодою відчути, що є якась об'єктивна дійсність, є якась об'єктивна правда... Ми навіть часом говоримо про те, що тепер є епоха постправди», - наголосив глава УГКЦ в авторській програмі Сергія Жадана на «Радіо НВ» (Жадан, 2020).

Переходимо безпосередньо до розгляду інформаційної взаємодії УГКЦ зі своїми вірними в період жорстокого карантину - з березня до 
травня 2020 року. У цьому процесі ми виділили два рівні - загальноукраїнський і місцевий.

3 початку квітня «Живе телебачення» як суспільно-релігійний проєкт УГКЦ, місією якого є залучення до своєї діяльності широкої аудиторії в Україні та за її межами, незалежно від національності та віку, християнської конфесії та суспільно-політичних переконань (про що зазначено на головній сторінці сайту цього проєкту), розпочало трансляцію різних типів богослужінь, також на телебаченні. Це сталося завдяки домовленості з керівництвом таких загальнонаціональних каналів як «UA: Суспільне», «4 канал», «5 канал» та ін. У квітні, у розпал всесвітньої пандемії, напередодні Великодня під проводом ієрархів УГКЦ «Живе телебачення» в мережі щодня транслювало молебень до Богородиці. Найчастіше зараз транслюють богослужіння з Патріаршого собору УГКЦ перші два названі канали. У проповідях під час богослужінь, які транслюються на медіаресурсі «Живе телебачення» глава УГКЦ Блаженніший Святослав та інші церковні владики, починаючи з весни минулого року й до сьогодні, закликають духовенство і вірних дотримуватися карантинних норм, встановлених Урядом України. Крім того, провід УГКЦ одним із перших відгукнувся на потребу допомагати ураженим від коронавірусу. Так, 22 березня 2020 року під час недільної проповіді Блаженніший Святослав (Шевчук) наголосив: «Як у часи Майдану, коли греко-католицькі храми, монастирі відкрилися й перетворилися на лікарні, на підпільні шпиталі,... якщо буде потрібно, весь церковний простір стане шпиталями, де ми разом із вами рятуватимемо людські життя» (Департамент інформації УГКЦ, 2020). Ця заява глави УГКЦ облетіла шпальти загальноукраїнських видань та наповнила стрічки впливових інтернет-видань.

Новою формою спілкування в онлайні на загальноцерковному рівні стало катехитичне навчання з метою підготовки до першої Сповіді й урочистого Причастя. «Катехитична школа онлайн» стала спільним проєктом «Живого телебачення» та Патріаршої катехитичної коміciї УГКЦ (Живе телебачення, 2020). Діти з греко-католицьких парафій з України й поселень на платформі Youtube «Живого телебачення» 3 весни й до серпня 2020 року навчалися у форматі 24 уроків, відповідно до визначеної програми підготовки. «Така школа мала колосальний успіх, крім того, вона об’єднала українських дітей Канади, Америки, Мексики, Іспанії, Португалії й аж до Казахстану й Зеленого Клину. Тобто географія нас просто здивувала...», - міркував глава УГКЦ у розмові із письменником Сергієм Жаданом на «Радіо НВ» (Жадан, 2020). Для того, щоби вести онлайн катехитичну школу, - продовжує далі Блаженніший Святослав, - треба бути професіоналом, не тільки вміти вживати сучасну технологію, але теж правильно фор- 
мулювати ті чи інші фрази, які би висловлювали вічні істини, шукати різного роду зображення... Сьогодні є замало комусь щось говорити, слухача потрібно робити учасником події, залучати, робити інтерактивний спосіб комунікації навіть онлайн. Ми багато чого навчилися (Жадан, 2020).

Коли в державі з осені минулого року фіксувалися тисячі уражених коронавірусом на день, на медіаресурсах УГКЦ в онлайн-форматі запроваджено ще один вид посиленої молитви за відвернення епідемії - молитву на вервиці (вервиця - це молитовні роздуми над таїнствами життя Ісуса Христа й Марії і водночас роздумами над Євангелієм. У римо-католиків практикують молитву на розаpiï, у православних - молитву на чотках). Із 14 жовтня, свята Покрову Пресвятої Богородиці, на ресурсі «Живе телебачення» розпочато проєкт «Вервиця єднає». Один раз у тиждень конкретний священнослужитель УГКЦ, незалежно від місця проживання, у прямому ефірі єднає українців цією формою молитви з усього світу.

Окрім загальнонаціонального рівня, інформаційна взаємодія УГКЦ перейшла й на місцевий рівень. У великих містах здебільшого Західної України трансляцію богослужінь та інших форм молитовних зібрань (наприклад, молитва на вервиці) із катедральних соборів і церков, починаючи з кінця березня минулого року, здійснювали на місцевих телеканалах щонеділі й у великі християнські свята (наприклад, з архикатедрального собору св. Юра у Львові це робив телеканал «НТА»). Така трансляція з квітня минулого року й до сьогодні - щодня, у неділю і свята - діє на платформі Youtube завдяки інтернет-провайдеру «Астра» («Астра», б.р.). Сотні тисяч вірних мають змогу слухати богослужіння із греко-католицьких церков міст і містечок здебільшого Західної України. При окремих храмах також налагоджено регулярну трансляцію богослужінь на каналі Youtube.

У соціальних мережах парафії, як маленькі адміністративні одиниці УГКЦ, почали молитовно діалогізувати із вірними. Наприклад, на фейсбук-сторінках ведеться щоденна трансляція богослужінь (у Гарнізонному храмі свв. Петра і Павла в самому центрі Львова, який є осередком капеланського служіння Львівської Архиєпархії УГКЦ і водночас місцем громадської активності вірян із цілого міста). У часі трансляцій богослужінь онлайн слухачі мають змогу публікувати в чаті свої наміри (за здоров’я, померлих, за різні життєві справи тощо).

Як наголошує дослідниця Н. Р. Гадьо, визначальною рисою католицького розуміння ЗСК є те, «що жодні технологічні можливості не замінять сакрального виміру та канонічних особливостей функціонування Католицької Церкви, тому інтернет-комунікація завжди буде тільки додатковим і допоміжним «місцем» католицької духовності» 
(Гадьо, 2020, с. 53). Католицьке розуміння терміна «комунікація», окрім трактування, притаманного журналістикознавству, - обмін інформацією та спілкування, містить значення «спільнота та спільність людей із Богом», а також, дослівно збережене донині в багатьох мовах, - «приймати Святе Причастя і здатність порозумітися». Відповідно до цього комунікація - не один із видів діяльності Католицької Церкви, а сама суть її життя, - зазначає дослідниця (Гадьо, 2020, с. 53). На початку 2019 року група викладачів Католицького університету в Мілані проводила дослідження у формі опитування, яке мало на меті «розслідувати» явище т. зв. «ліквідного суспільства», тобто того, що не в змозі збудувати стосунки та спільноту, визначаючи при цьому місця, де навпаки, має місце турбота про стосунки та громаду. Розслідування підтвердило, з допомогою методу протилежності, що «існують місця, де турбота про стосунки та взаємовідносини є базовою, такі як, наприклад, парафії. Тоді ми зіштовхнулися із тим, щоби досліджувати нову й немислиму ситуацію» (Lenzi, 2021). Насправді перше повномасштабне опитування, на яке повністю відповіли 420 італійських парафій із кінця 2019 року до початку 2020 року показало ситуацію, яка ще не стосувалася періоду пандемії та її обмежень на всіх рівнях. Потім команда професорів та дослідників із Католицького університету другу анкету адресувала лише тим парафіям, які відповіли на першу. Результати показали, що більше однієї парафії 3 двох регулярно використовує WhatsApp та Telegram (56\%), електронну пошту (54\%) та сторінку Facebook (50\%) для підтримання контактів та будування взаємовідносин у парафіяльній спільноті. Використання Twitter (15\%) та Instagram (26\%), безумовно, реалізовується менше (Lenzi, 2021). Подібну інформаційну взаємодію на рівні парафій УГКЦ в Україні розпочнуть вивчати, можливо, з часом із допомогою фахівців в умовах уже післяпандемічного світу.

Ще однією новою формою спілкування УГКЦ із вірянами стали великопосні реколекції в інтернеті, зокрема, на каналі Youtube. Власне жорстка фаза першої хвилі коронавірусу припадає на період Великого посту для католиків на цілій земній кулі. За традицією УГКЦ саме в такий період літургійного року сотні священнослужителів в Україні в соборах, церквах, малих храмах тощо беруть участь у поглибленні духовного життя 3 допомогою таких форм, як великопосні реколекції (духовні науки й інші практики тривають до трьох днів) і місії (духовні науки й інші практики тривають до тижня). Найбільш активні з поміж числа реколектантів, наприклад, священники УГКЦ чернечого Чину св. Василія Великого (отці василіани) в Україні, серед них, зокрема, Корнилій Яремак, Йосиф Будай зі львівського монастиря св. Онуфрія записали низку таких відеонаук на Youtube для піднесення духу вірних і для духовної підготовки зустрічі Пасхи. Отець 
Корнилій Яремак присвятив низку відеолекцій тому, як християнам треба 3 релігійної точки зору ставитися до таких викликів, як жорсткий карантин, як його переживати, не вірячи у всілякі «теорії змови», а зберігаючи життя своїх ближніх, що й лежить в основі християнської любові (Василіяни: українська Провінція, 2021). Названий священник бере участь у програмі «Живого радіо» (один із медіаресурсів УГКЦ) під назвою «Вечірні діалоги з душпастирем». Ієромонах Йосиф Будай у своїх інтернет-науках на платформі Youtube подавав цікаві приклади із понад 40-річного священничого й монашого служіння як у період підпілля, так і за часів незалежності (Семінарія оо. Василіян, 2020). Душпастирське навчання на каналі Youtube з моменту ситуативного послаблення карантинних обмежень у травні 2020 року й надалі розвивається. Найбільш показовими прикладами тут $€$ відеоблоги й короткі відеонауки о. Сергія Гончарова, монаха Чину Найсвятішого Ізбавителя (отці редемптористи) із монастиря в Тернополі, під псевдонімом «падре Серж», виходця із Білорусі. Його канал із 2014 року має майже 15 тис. підписників, завоював передусім увагу серед тисяч воцерковленої (і не тільки) молоді (Падре Серж, б.р.). Регулярно веде свій канал під назвою «Християнин чи бандит?» священник храму свв. Володимира й Ольги у Львові, д-р Михайло Димид, який має понад 3 тисячі підписників (Християнин чи бандит?, 2020). Youtube-проповідники і блогери приваблюють аудиторію легким і нетрадиційним поясненням релігійних питань сьогодення (у розумінні висловлення форм, образів, символів). Популярний до цього часу інтернет-проповідник серед спільнот із напрямом поглибленого християнського життя о. Онуфрій Репецький із монастиря в м. Кам'янець-Подільський на Хмельниччині, регулярно служить духовним словом тисячам підписників до сьогодні (Репецький, 2021). 33-річний греко-католицький священник Тарас Бровді із с. Ділового на Закарпатті під час карантину почав знімати мотиваційні, розважальні відео, у яких намагається зруйнувати стереотипи про релігію і Церкву. За 9 місяців розвитку його Youtube-каналу до нього приєдналося понад 5 тисяч підписників (ХоДІМ, б.р.). Технологію створення відеороликів він опанував як самостійно, так і користуючись порадами друзів щодо контенту.

Таких прикладів проповідництва в мережі можна наводити десятки в регіональному вимірі служіння УГКЦ. Це була якісна відповідь місцевого церковного середовища на запит аудиторії, яка спрагла поглибленого духовного слова в часі епідемії і в умовах меншої соціалізації.

Із досвіду медійної діяльності Католицької Церкви в Польщі під час карантину станом на початок 2021 року випливає, що вона в деяких формах нагадує інформаційну взаємодію УГКЦ на загальноукраїнському та місцевому рівнях. Підтвердженням цьому послужать 
тези доповіді дослідниці з Варшавського університету, д-ра Мілени Кіндзюк на конференції в Бєльсько-Бялій академії (Польща). По-перше, це трансляція щоденних літургій в онлайні з великих катедральних соборів, храмів і монастирських церков, де відбуваються традиційно багатотисячні паломництва (при цьому світські 3МІ роблять анонси таких трансляцій). По-друге, трансляція урочистих мес і похоронних богослужінь (під час одного з них зафіксовано 188 тис. онлайн-глядачів (!), що було б нереальним навіть у позакарантинному часі). По-третє, трансляція в соціальних мережах і на Youtube-каналах духовних наук священників, молитовних заходів у спільнотах при костелах; трансляція молитви на розарії тощо. Одними 3 найактивніших у мережі стали монахи ордену домініканців, а популярність відеоблогера цієї монашої спільноти на Youtube о. Адама Шустака зросла ще більше (Kindziuk, 2021). Д-р Мілена Кіндзюк наголосила, що в такий спосіб формується «нова модель віри», у якій, хоч з'явилися нові можливості для спілкування Церкви в онлайні зі своїми вірянами, натомість частина з них після закінчення пандемії може не повернутися в костели для практикування своєї віри й духовності (Kindziuk, 2021). У тезах доповіді м-ра Катажини Радванської з папського Університету ім. Івана Павла II $є$ згадка про один із мотиваційних транспарантів, який з'явився в той час: «Ми скучили за вами. Ваші священники» (Radwanska, 2021).

Висновки

УГКЦ з березня 2020 року шукає ефективні форми інформаційної взаємодії в суспільному контексті.

У світських 3МІ в Україні з'явилося більше коментарів ієрархів та медійно активних священнослужителів УГКЦ. Вони апелюють до свідомості журналістів поширювати правдиву інформацію щодо позиції УГКЦ у питанні пандемії і водночас пропагувати в ЗМІ дотримання карантинних вимог із боку влади.

Журналісти зі сфери культурної та релігійної тематики почали позиціонувати УГКЦ як таку, що словом лікує тих, хто страждає не тільки від коронавірусу, а й від інших хвороб.

Інформаційна взаємодія УГКЦ відбувається на двох рівнях - загальноукраїнському та місцевому. Для першого задіяно всі можливі онлайн-платформи для донесення літургійних практик і віровчення, на другому ініціативу в поширенні науки Церкви беруть самі священнослужителі чи окремі монаші спільноти, водночас навчаючись новим технологіям. На місцевому рівні парафії стали відігравати роль «домашньої церкви», щоденно транслюючи через соцмережі літургії чи науки про віру й духовність. Подібна інформаційна взаємодія Католицької Церкви відбувається й у країнах ЄС, що автор планує в перспективі глибше вивчати. 


\section{СПИСОК БІБЛІОГРАФІЧНИХ ПОСИЛАНЬ}

Астра: інтернет-провайдер. (б.р.). Головна [Канал YouTube]. Взято 18 січня, 2021, 3 https://www.youtube.com/channel/UCe8yZnZIfsaXmBIraBmhAMA

Блажиєвський, Ю. (2020, 15 травня). Отець Юрій Блажиєвський: «Нам страшенно бракує аналітики на релігійні теми, яка би опиралася на фахову експертну думку» (Інтерв’юер I. Скленар). Релігійно-інформаційна служба України. Взято 18 січня, 2021, з https://risu.org.ua/ua/index/expert_thought/ interview/80196/

Бойко, А. А. (2016). Релігійна журналістика. Видавничо-поліграфічний центр «Київський університет».

В Україні зросла кількість незареєстрованих релігійних громад - статистика Мінкультури. (2020, 12 червня). Інститут релігійної свободи. Взято 18 січня, 2021, 3 https://irs.in.ua/ua/statistics-of-religious-organizations-in-ukraine-2020

Василіяни: українська Провінція. (2020, 29 березня). Роздуми під час пандемії. Наука 1 [Відео]. YouTube https://www.youtube.com/ watch?v=XLmjETY78AI\&t=17s

Гадьо, Н. (2020). Місійна діяльність Католицької Церкви як головна підстава формування медіастратегій в інтернеті. Вісник Львівського університету. Серія: Журналістика, 48, 49-55. http://dx.doi.org/10.30970/vjo.2020.48.10544

Гудзяк, Б. (2020, 19 квітня). Карантинний Великдень. Новое время. https:// nv.ua/ukr/opinion/velikden-2020-boris-gudzyak-pro-cerkvu-ta-karantin-noviniukrajini-50083062.html

Департамент інформації УГКЦ. (2020, 22 березня). Блаженніший Святослав звернувся до медиків: «Якщо буде потрібно, увесь церковний простір стане шпиталями». Інформаційний ресурс Української Греко-Католицької Церкви. Взято 18 січня, 2021, з http://news.ugcc.ua/video/blazhenn\%D1\%96shiy svyatoslav_zvernuvsya_do_medik\%D1\%96v_yakshcho_bude_potr\%D1\%96bno_ uves_tserkovniy_prost\%D1\%96r_stane_shpitalyami_89028.html

Жадан, С. (2020, 05 листопада). Бог і машини. Інтерв’ю Жадана з главою УГКЦ Святославом: епоха постправди, роботизація світу й релігія у 2020 році. Новое время. https://nv.ua/ukr/ukraine/events/zhadan-i-glava-ugkc-vladikasvyatoslav-pro-postpravdu-robotiv-ta-boga-interv-yu-novini-ukrajini-50122237. html

Живе телебачення. (2020, 13 травня). 1-й урок Боже ім'я. Катехитична онлайн школа Промінь світла [Відео]. YouTube. https://www.youtube.com/watch?v=dv3A KPNAbHU\&feature=youtu.be

Падре Серж. (б.р.). Головна [Канал ҮоuTube]. Взято 18 січня, 2021 з https://www. youtube.com/channel/UCAkH-mhUcDi5RR-p38P7OdQ

Репецький, О. (2021, 15 січня). Слово це жива вода, що омиває душу [Відео]. Facebook. https://www.facebook.com/ot.onufriy/videos/3402037906590443

Семінарія оо. Василіян. (2020, 9 квітня). Отець Йосиф Будай, ЧСВВ. Про молитву (ч. 1). Перша реколекційна наука [Відео]. YouTube. https://www.youtube. $\mathrm{com} /$ watch?v=XUW6i0YIDI4\&list=PLbE2GXx-P8efqR6YqKh4CfrDkRK2YSXrY\&in $\operatorname{dex}=14$

Телеканал НТА. (2020, 21 квітня). Боротьба з коронавірусом перетворилася на боротьбу з Церквою! Юстин Бойко [Відео]. YouTube. https://www.youtube.com/ watch?v=rKekqe2GCQE 
Християнин чи бандит? (2020, 11 грудня). Гороскоп для християн! [Відео]. YouTube. https://www.youtube.com/watch?v=ay5zCF16xmk

Kindziuk, M. (2020, December 17). Transmisje nabożenstw i uroczystośći religijnych on line w okresie pandemii COVID19. Nowa era medialna. http://www. konferencjamedia.ath.bielsko.pl/images/do-pobrania/harmonogram2.pdf

Lenzi, E. (2021, January 22). Indagine. Una parrocchia su due «usa»i social. La svolta? La pandemia. Avvenire. Retrieved January 18, 2021, from https://www. avvenire.it/chiesa/pagine/in-italia-la-parrocchia-si-scopre-piu-social

Radwańska, K. (2020, December 17).e-Kościół - przegliąd medialnych dzialań wspólnoty w czasie pierwszego lockdownu. http://www.konferencjamedia.ath.bielsko. pl/images/do-pobrania/harmonogram2.pdf

\section{REFERENCES}

Astra: internet-provaider. (n.d.). Home [YouTube channel]. Retrieved January 18, 2021, from https://www.youtube.com/channel/UCe8yZnZIfsaXmBIraBmhAMA [in Ukrainian].

Blazhyievskyi, Yu. (2020, May 15). Otets Yurii Blazhyievskyi: «Nam strashenno brakuie analityky na relihiini temy, yaka by opyralasia na fakhovu ekspertnu dumku» [Father Yuri Blazhievsky: «We are Terribly Short of Analysts on Religious Topics, Which Would be Based on Professional Expert Opinion»] (Interviewer I. Sklenar). Relihiino-informatsiina sluzhba Ukrainy. Retrieved January 18, 2021, from https:// risu.org.ua/ua/index/expert_thought/interview/80196/ [in Ukrainian].

Boiko, A. A. (2016). Relihiina zhurnalistyka [Religious Journalism]. Vydavnycho-polihrafichnyi tsentr «Kyivskyi universytet» [in Ukrainian].

Departament informatsii UHKTs. (2020, March 22). Blazhennishyi Sviatoslav zvernuvsia do medykiv: «Iakshcho bude potribno, uves tserkovnyi prostir stane shpytaliamy» [His Beatitude Sviatoslav Addressed the Doctors: «If Necessary, the Whole Church Space will Become Hospitals»]. Informatsiinyi resurs Ukrainskoi Hreko-Katolytskoi Tserkvy. Retrieved January 18, 2021, from http://news.ugcc. ua/video/blazhenn\%D1\%96shiy_svyatoslav_zvernuvsya_do_medik\%D1\%96v_ yakshcho_bude_potr\%D1\%96bno_uves_tserk̄ovniy_prost\%D1\%96r_stane_ shpitalyami_89028.html [in Ukrainian].

Gudziak, B. (2020, April 19). Karantynnyi Velykden [Quarantine Easter]. Novoe vremia. https://nv.ua/ukr/opinion/velikden-2020-boris-gudzyak-pro-cerkvu-takarantin-novini-ukrajini-50083062.html [in Ukrainian].

Hado, N. (2020). Misiina diialnist Katolytskoi Tserkvy yak holovna pidstava formuvannia mediastratehii v interneti [Missionary Activity of the Catholic Church as the Main Ground for Media Strategies on the Internet]. Visnyk of the Lviv University. Series Journalism, 48, 49-55. http://dx.doi.org/10.30970/ vjo.2020.48.10544 [in Ukrainian].

Khrystyianyn chy bandyt? (2020, December 11). Horoskop dlia khrystyian! [Horoscope for Christians!] [Video]. YouTube. https://www.youtube.com/ watch? $\mathrm{v}=$ ay $5 \mathrm{zCF} 16 \mathrm{xmk}$ [in Ukrainian].

Kindziuk, M. (2020, December 17). Transmisje nabożenstw i uroczystośći religijnych on line w okresie pandemii COVID19. Nowa era medialna [Online Transmissions of Services and Religious Celebrations During the COVID19 Pandemic. A New Media Era]. http://www.konferencjamedia.ath.bielsko.pl/images/do-pobrania/ harmonogram2.pdf [in Polish]. 
Lenzi, E. (2021, January 22). Indagine. Una parrocchia su due «usa» i social. La svolta? La pandemia [Investigation. One in Two Parishes «Use» Social Media. The Turning Point? The Pandemic]. Avvenire. Retrieved January 18, 2021, from https:// www.avvenire.it/chiesa/pagine/in-italia-la-parrocchia-si-scopre-piu-social [in Italian].

Padre Serzh. (n.d.). Home [YouTube channel]. Retrieved January 18, 2021, from https://www.youtube.com/channel/UCAkH-mhUcDi5RR-p38P7OdQ [in Ukrainian].

Radwańska, K. (2020, December 17).e-Kościół - przegliąd medialnych dzialań wspólnoty w czasie pierwszego lockdownu [e-Church - an Overview of Community Media Activities During the First Lockdown]. http://www.konferencjamedia.ath. bielsko.pl/images/do-pobrania/harmonogram2.pdf [in Polish].

Repetskyi, O. (2021, January 15). Slovo tse zhyva voda, shcho omyvaie dushu [The Word is Living Water that Washes the Soul] [Video]. Facebook. https://www. facebook.com/ot.onufriy/videos/3402037906590443 [in Ukrainian].

Seminariia oo. Vasyliian. (2020, April 9). Otets Yosyf Budai, ChSVV. Pro molytvu (ch. 1). Persha rekolektsiina nauka [Father Yosyf Budai, OSBM. About Prayer (pt. 1). The First Retreat Science] [Video]. YouTube. https://www.youtube.com/watc h?v=XUW6i0YIDI4\&list=PLbE2GXx-P8efqR6YqKh4CfrDkRK2YSXrY\&index=14 [in Ukrainian].

Telekanal NTA. (2020, April 21). Borotba z koronavirusom peretvorylasia na borotbu $z$ Tserkvoiu! Yustyn Boiko [The Fight Against the Coronavirus Has Turned Into a Fight Against the Church! Yustyn Boyko] [Video]. YouTube. https://www.youtube. $\mathrm{com} /$ watch?v=rKekqe2GCQE [in Ukrainian].

V Ukraini zrosla kilkist nezareiestrovanykh relihiinykh hromad - statystyka Minkultury [In Ukraine, the Number of Unregistered Religious Communities Has Increased - Statistics from the Ministry of Culture]. (2020, June 12). Instytut relihiinoi svobody. Retrieved January 18, 2021, from https://irs.in.ua/ua/statisticsof-religious-organizations-in-ukraine-2020 [in Ukrainian].

Vasyliiany: ukrainska Provintsiia. (2020, March 29). Rozdumy pid chas pandemii. Nauka 1 [Reflections During a Pandemic. Science 1] [Video]. YouTube https://www. youtube.com/watch?v=XLmjETY78AI\&t=17s [in Ukrainian].

Zhadan, S. (2020, November 5). Boh i mashyny. Interv'iu Zhadana z hlavoiu UHKTs Sviatoslavom: epokha postpravdy, robotyzatsiia svitu y relihiia u 2020 rotsi [God and Machines. Zhadan's Interview with the Head of the UGCC Sviatoslav: the Post-Truth Era, the robotization of the World and Religion in 2020]. Novoe vremia. https://nv.ua/ukr/ukraine/events/zhadan-i-glava-ugkc-vladika-svyatoslavpro-postpravdu-robotiv-ta-boga-interv-yu-novini-ukrajini-50122237.html [in Ukrainian].

Zhyve telebachennia. (2020, May 13). 1-i urok Bozhe im'ia. Katekhytychna onlain shkola Promin svitla [Lesson 1 God's Name. Catechetical Online School Ray of Light] [Video]. YouTube. https://www.youtube.com/ watch?v=dv3AKPNAbHU\&feature=youtu.be [in Ukrainian]. 